\begin{tabular}{|l|l|l|}
\hline \multicolumn{2}{|c|}{ PublisherInfo } \\
\hline \hline PublisherName & $:$ & BioMed Central \\
\hline \hline PublisherLocation & $:$ & London \\
\hline \hline PublisherImprintName & $:$ & BioMed Central \\
\hline \hline
\end{tabular}

\title{
Oncogenic phosphatase amplification
}

\begin{tabular}{|l|c|l||}
\hline \multicolumn{2}{|c|}{ ArticleInfo } \\
\hline \hline ArticleID & $:$ & 4488 \\
\hline \hline ArticleDOI & $:$ & $10.1186 /$ gb-spotlight-20020523-01 \\
\hline \hline ArticleCitationID & $:$ & spotlight-20020523-01 \\
\hline \hline ArticleSequenceNumber & $:$ & 154 \\
\hline \hline ArticleCategory & $:$ & Research news \\
\hline ArticleFirstPage & $:$ & 1 \\
\hline \hline ArticleLastPage & $:$ & 2 \\
\hline \hline & & RegistrationDate : 2002-5-23 \\
\hline ArticleHistory & $:$ & OnlineDate \\
\hline \hline ArticleCopyright & $:$ & BioMed Central Ltd2002-5-23 \\
\hline \hline ArticleGrants & $:$ & \\
\hline \hline ArticleContext & $:$ & 130593311 \\
\hline \hline
\end{tabular}




\section{Jonathan B Weitzman}

Email: jonathanweitzman@hotmail.com

Post-translational regulation of p53 regulates its activity and tumour suppressor functions. In an Advanced Online Publication in Nature Genetics, Bulavin et al. from the National Institutes of Health describe how oncogenic Ras regulates p53 phosphorylation (Nature Genetics 20 May 2002, DOI:10.1038/ng894). Using antibodies specific for different modified forms of p53 they showed that oncogenic Ras induced p53, accumulation and phosphorylation of two specific serine residues that are substrates of p38 MAP kinase Bulavin et al. found that the p53-inducible phosphatase PPMID abrogates p53 phosphorylation indirectly by inhibiting MAP kinase activity; overexpression of $P P M 1 D$ was oncogenic in $\mathrm{p} 53$-expressing cells. They found evidence for amplification and overexpression of the human PPM1D gene in breast cancer cells expressing wild-type p53. An accompanying report by Li $e t$ al. provides additional evidence for $P P M 1 D$ locus amplification and overexpression in breast cancer cells (Nature Genetics 20 May 2002, DOI:10.1038/ng888). These results suggest that amplification of the chromosome $17 \mathrm{q} 22 / 24$ region containing the PPM1Dgene suppresses p53 function by regulating post-translational modification.

\section{References}

1. Post-translational modifications and activation of $\mathrm{p} 53$ by genotoxic stresses.

2. Nature Genetics, [http://www.nature.com/ng/]

3. National Institutes of Health, [http://www.nih.gov]

4. Phosphorylation of human $\mathrm{p} 53$ by p38 kinase coordinates N-terminal phosphorylation and apoptosis in response to UV radiation. 